Pena Justisia: Media Komunikasi dan Kajian Hukum
Vol. 18, No. 2, 2019
Artikel Hasil Penelitian

\title{
PERLINDUNGAN HUKUM BAGI INVESTOR DALAM PASAR MODAL MENURUT UNDANG-UNDANG PASAR MODAL DAN UNDANG-UNDANG OTORITAS JASA KEUANGAN
}

Vidya Noor Rachmadini**

**Fakultas Hukum Universitas Padjajaran. Email: vidya.rachmadini@gmail.com

\begin{tabular}{l}
\hline Info Artikel \\
\hline Keywords: \\
Legal Protection, Consumer Interests, \\
The Capital Market \\
Kata kunci: \\
Perlindungan Hukum, Kepentingan \\
Konsumen, Pasar Modal
\end{tabular}

\begin{abstract}
Legal Protection for Investors in the Capital Market. Supervision in the financial services industry capital markets experienced a change of control by Bapepam-LK be supervised by the Financial Services Authority. Institutionally, Bapepam-LK is responsible to the Minister of Finance, as Bapepam-LK is under the auspices of the Ministry of Finance, while the Financial Services Authority is responsible to Parliament or the public. Crucial aspect on which the formation of the FSA is not maximum protection of the interests of consumers of financial services. In accordance with the problems that occur as above, the authors feel the need to examine the legal protection in the capital market. This writing will also examine the parties are entitled to legal protection based on Law No. 8 of 1995 and the Capital Market Law No. 21 of 2011 on the Financial Services Authority.
\end{abstract}

\begin{abstract}
Abstrak
Perlindungan Hukum Bagi Investor Dalam Pasar Modal. Pengawasan di bidang industri jasa keuangan pasar modal mengalami perubahan dari pengawasan yang dilakukan oleh Bapepam-LK menjadi diawasi oleh Otoritas Jasa Keuangan. Secara kelembagaan, Bapepam-LK bertanggung jawab kepada Menteri Keuangan, karena Bapepam-LK berada di bawah naungan Kementrian Keuangan, sedangkan Otoritas Jasa Keuangan bertanggung jawab kepada Dewan Perwakilan Rakyat atau masyarakat. Aspek krusial yang menjadi dasar pembentukan OJK adalah tidak maksimalnya perlindungan kepentingan konsumen jasa keuangan. Sesuai dengan permasalahan yang terjadi seperti diatas, maka penulis merasa perlu untuk meneliti tentang perlindungan hukum di pasar modal. Penulisan ini juga akan meneliti para pihak yang berhak atas perlindungan hukum berdasarkan pada UndangUndang Nomor 8 Tahun 1995 Tentang Pasar Modal dan Undang-Undang Nomor 21 Tahun 2011 Tentang Otoritas Jasa Keuangan.
\end{abstract}

\section{PENDAHULUAN}

Perlindungan hukum merupa-kan salah satu unsur untuk memperbaiki aspek penegakan hukum di suatu negara. Tentunya perlindungan hukum diberikan oleh negara kepada masyarakatnya demi mewujudkan stabilitas dalam hal apapun, termasuk di dalamnya dalam hal ekonomi dan hukum. 
Menurut terminologi perlindungan hukum, pengertian perlindungan hukum dapat dipisahkan menjadi dua kata yaitu perlindungan dan hukum. ${ }^{1}$

Secara kebahasaan, kata perlindungan dalam bahasa Inggris disebut dengan protection. Istilah perlindungan menurut Kamus Besar Bahasa Indonesia (KBBI) dapat disamakan dengan istilah proteksi, yang artinya adalah proses atau perbuatan memperlindungi, sedangkan menurut Black's Law Dictionary, protection adalah the act of protecting. ${ }^{2}$ Pasar modal / Capital Market / Stock Exchange / Stock Market dalam pengertian klasik diartikan sebagai suatu bidang usaha perdagangan surat-surat berharga seperti saham, sertifikat saham, dan obligasi atau efek-efek pada umumnya. Sementara itu, pasar modal menurut Kamus Hukum Ekonomi diartikan sebagai pasar atau tempat bertemunya penjual dan pembeli yang memperdagangkan surat-surat berharga jangka panjang misalkan saham dan obligasi. ${ }^{3}$

Karena kegiatan pasar modal begitu marak dan complicated, maka sangat dibutuhkan suatu perangkat hukum yang mengaturnya agar pasar tersebut teratur, wajar, dan adil bagi semua pihak. Atas dasar semua itu, lahirlah Hukum Pasar Modal (Capital Market Law/ Securities Law). Hukum pasar modal adalah norma-norma hukum atau aturan-aturan hukum yang mengatur tentang segala segi yang berhubungan dengan pasar modal. ${ }^{4}$ Dalam suatu investasi, perlindungan hukum sangat diperlukan untuk melindungi investor dari resiko yang harus ditanggung oleh investor itu sendiri dalam melasanakan kegiatan investasi. Di Bursa Efek Jakarta misalnya, beberapa kasus tindakan manipulasi pasar pernah terditeksi, tetapi tidak semua pelaku dapat tertangkap. Jika tidak hati-hati, bahkan dapat juga terjadi sanksi yang dijatuhkan kepada pihak yang sebenarnya bukan sebagai pelaku yang bersalah melakukan kejahatan dan secara rational tidak bersalah sama sekali. Karena itu, diperlukan penafsiran dari ketentuan pasar modal yang ada saat ini yang lebih kondusif agar tercipta keadilan, ketertiban, dan efektifitas tetapi juga dengan tetap memiliki unsur kepastian hukum. $^{5}$

Dari latar belakang di atas, penulis tertarik untuk menyusun jurnal dengan judul, "Perlindungan Hukum Bagi Investor Dalam Pasar Modal Menurut Undang-Undang Pasar Modal dan UndangUndang Otoritas Jasa Keuangan". Tulisan ini akan membahas dan mengkaji mengenai Perlindungan Hukum Bagi Investor Dalam Pasar Modal Menurut Undang-Undang Nomor 8 Tahun 1995 Tentang Pasar Modal Dan Undang-Undang Nomor 21 Tahun 2011 Tentang Otoritas Jasa Keuangan.

\section{PEMBAHASAN}

\section{Bentuk Perlindungan Hukum}

Menurut R. La Porta dalam Journal of Financial Economics, bentuk perlindungan hukum yang diberikan oleh suatu negara memiliki dua sifat, yaitu bersifat pencegahan (probibited) dan bersifat

\footnotetext{
${ }^{1}$ Bagus Sujatmiko and Nyulistiowati Suryanti, 'Perlindungan Hukum Bagi Investor Pada Perusahaan Terbuka Yang Pailit Ditinjau Dari Hukum Kepailitan', Jurnal Bina Mulia Hukum, 2.1 (2017), 15-25 <https://doi.org/10.23920/jbmh.v2n1.2>.

${ }_{2}$ Rahmadiani Putri Nilasari, 'Perlindungan Hukum Terhadap Investor Dalam Transaksi Jual Beli Efek Melalui Internet', Yuridika, 26.3 (2011), 275-86 <https://doi.org/10.20473/ydk.v26i3.279>.

${ }^{3}$ Noviasih Muharam, 'Perlindungan Hukum Bagi Investor Dalam Pembelian Kembali Sahamnya', Pranata Hukum, 13.1 (2018), 59-71 <https://doi.org/10.36448/pranatahukum.v13i1.177>.

${ }_{4}$ Ahmad Dwi Nuryanto, 'Problem Penyidikan Tindak Pidana Pencucian Uang Yang Berasal Dari Predicate Crime Perbankan', Bestuur, 7.1 (2019), 54 <https://doi.org/10.20961/bestuur.v7i1.43437>.

${ }^{5}$ Ferry Kiandi, 'Perlindungan Hukum Dalam Transaksi Margin Trading Dan Short Sales Di Pasar Modal', FH Universitas Sumatera Utara, 2014, 1-18.
} 
hukuman (sanction). ${ }^{6}$ Bentuk perlindungan hukum yang paling nyata adalah adanya institusi-institusi penegak hukum seperti pengadilan, kepolisian dan lembaga penyelesaian sengketa diluar pengadilan (non-litigasi) lainnya. Hal ini sejalan dengan pengertian hukum menurut Soedjono Dirdjosisworo yang menyatakan bahwa hukum memiliki pengertian beragam dalam masyarakat dan salah satu yang paling nyata dari pengertian tentang hukum adalah adanya institusi-institusi penegak hukum. ${ }^{7}$

Perlindungan hukum sangat erat kaitannya dengan aspek keadilan. Menurut pendapat Soediman Kartohadiprodjo, pada hakikatnya tujuan adanya hukum adalah mencapai keadilan. Maka dari itu adanya perlindungan hukum merupakan salah satu medium untuk menegakkan keadilan salah satunya penegakkan keadilan di bidang ekonomi khususnya pasar modal. Penegakan hukum dalam bentuk perlindungan hukum dalam kegiatan ekonomi bisnis khususnya pasar modal tidak bisa dilepaskan dari aspek hukum perusahaan ${ }^{8}$ khususnya mengenai perseroan terbatas, karena perlindungan hukum dalam pasar modal melibatkan para pihak pelaku pasar modal terutama pihak emiten, investor dan lembaga-lembaga penunjang kegiatan pasar modal yang mana para pihak tersebut didominasi oleh subjek hukum berupa badan hukum berbentuk perseroan terbatas.'

Subjek hukum dalam hukum perdata terdapat dua subjek hukum, yaitu subjek hukum orang pribadi dan subjek hukum berupa badan hukum. Subjek hukum orang pribadi atau natuurlijkepersoon adalah orang atau manusia yang telah dianggap cakap menurut hukum. Orang sebagai subjek hukum merupakan pendukung atau pembawa hak sejak ia dilahirkan hidup sampai ia mati ${ }^{10}$ walaupun ada pengecualian bahwa bayi yang masih dalam kandungan ibunya dianggap telah menjadi sebagai subjek hukum sepanjang kepentingannya mendukung untuk itu. ${ }^{11}$

Selanjutnya, subjek hukum dalam hukum perdata adalah badan hukum atau rechtspersoon. Badan hukum merupakan kumpulan manusia pribadi atau pula dapat merupakan kumpulan dari badan hukum. Pembagian badan hukum ada dua bentuk, yaitu badan hukum publik atau Publiek Rechtspersoon dan badan hukum privat atau Privaat Rechtspersoon. Menurut Satjipto Rahardjo, hukum melindungi kepentingan seseorang dengan cara mengalokasikan kekuasaan kepadanya untuk bertindak dalam rangka kepentingannya secara terukur. Kepentingan merupakan sasaran dari hak karena hak mengandung unsur perlindungan dan pengakuan. Jadi, dapat disimpulkan bahwa perlindungan hukum atau legal protection merupakan kegiatan untuk menjaga atau memelihara masyarakat demi mencapai keadilan. Kemudian perlindungan hukum dikonstruksikan sebagai: a) Bentuk pelayanan, pelayanan ini diberikan oleh aparat penegak hukum dan aparat keamanan, b) Subjek yang dilindungi. ${ }^{12}$

\section{Perlindungan Hukum Bagi Investor Menurut Undang-Undang Nomor 8 Tahun 1995 Tentang Pasar Modal.}

Dalam pasal 4 Undang-Undang Nomor 8 Tahun 1995 Pasar Modal dinyatakan bahwa "Pembinaan, pengaturan, pengawasan sebagaimana dimaksud dalam Pasal 3 dilaksanakan oleh

${ }^{6}$ Inda - Rahadiyan and Diah Ayu Ambarsari, 'Ketiadaan Batas Waktu Suspensi Dan Implikasinya Terhadap Perlindungan Investor Pasar Modal Indonesia', Jurnal Hukum Ius Quia Iustum, 25.2 (2018), 300-319 $<$ https://doi.org/10.20885/iustum.vol25.iss2.art5>.

${ }^{7}$ Oleh Made and Dwi Juliana, 'Perlindungan Hukum Terhadap Investor Bila Terjadi Insider Trading Dalam Pasar Modal', Kertha Wicara, Vol.2, No. (2013), 1-5.

${ }^{8}$ Sutantya R. Hadhikusuma dan Sumantoro, Pengertian Pokok. Hukum Perusahaan: Bentuk-bentuk perusahaan yang berlaku di Indonesia, PT. Raja Grafindo Persada, Jakarta, 1996, hal 5-8.

${ }^{9}$ Muharam.

${ }^{10}$ H.R. Sardjono dan Frieda Husni Hasbullah, Bunga Rampai Perbandingan Hukum Perdata, hal 143.

11 Liana E Susanti, 'Economic Law Creation Beautiful Global Indonesia', Bestuur, 7.1 (2019), 47-53 $<$ https://jurnal.uns.ac.id/bestuur/article/view/42701>.

12 Dian Husna Fadlia and. Yunanto, 'Peran Otoritas Jasa Keuangan (Ojk) Dalam Perlindungan Hukum Bagi Investor Atas Dugaan Investasi Fiktif, Law Reform, 11.2 (2015), 207 <https://doi.org/10.14710/lr.v11i2.15768>. 
Bapepam dengan tujuan mewujudkan terciptanya kegiatan Pasar Modal yang teratur, wajar, dan efisien serta melindungi kepentingan pemodal dan masyarakat." Rezim Undang-Undang Nomor 8 Tahun 1995 Tentang Pasar Modal (selanjutnya disebut UUPM) menentukan dan mengatur bahwa otoritas yang berwenang atas pasar modal adalah Bapepam-LK. Otoritas ini berada di bawah Kementerian Keuangan untuk membina, mengatur, dan mengawasi pasar modal. Dalam kegiatannya, Bapepam-LK berada di bawah dan bertanggung jawab kepada Menteri Keuangan. Bapepam-LK lah yang memiliki wewenang untuk melaksanakan perlindungan hukum pasar modal yang bersifat preventif dan represif. ${ }^{13}$

Dalam rezim UUPM, Bapepam-LK merupakan pengejawantahan institusi untuk mengembalikan kepercayaan masyarakat terhadap pasar yang mengalami depresi sejak munculnya krisis keuangan di sejumlah negara Asia. Pada akhirnya pun kiris keuangan inilah yang turut menjadi salah satu faktor pembentukan OJK sebagai lembaga pengawas jasa keuangan di Indonesia. Untuk melindungi investor maka pihak emiten yang akan menjual efek dalam Penawaran Umum harus memberikan kesempatan kepada investor untuk membaca prospektus berkenaan dengan efek yang diterbitkan, sebelum pemesanan ataupun pada saat pemesanan dilakukan. Pada akhirnya setelah Bapepam-LK memperhatikan kelengkapan dan kejelasan dokumen emiten untuk melakukan Penawaran Umum demi memenuhi prinsip keterbukaan pasar modal. Hal ini penting mengingat prospektus atas efek merupakan pintu awal dan waktu untuk mempertim-bangkan bagi investor apakah akan memutuskan membeli atau tidak atas suatu efek. ${ }^{14}$

Tindakan pencegahan selanjut-nya yang dilakukan oleh Bapepam-LK adalah mengatur bahwa prospektus efek dilarang memuat konten menyesatkan atau keterangan yang tidak benar tentang Fakta Material ${ }^{15}$ atau menyajikan informasi tentang kelebihan dan kekurangan efek yang ditawarkan. Dalam praktiknya Bapepam-LK membuat standar penyusunan prospektus atas efek yang akan ditawarkan. Tindakan perlindungan ini dimulai pada saat Bapepam-LK memberikan izin terhadap SRO, Reksadana, perusahaan efek, maupun profesi-profesi penunjang untuk berkegiatan di pasar modal. Selain tindakan pencegahan, Bapepam-LK juga berwenang untuk melakukan pemeriksaan dan penyidikan. Hal ini merupakan konsekuensi dari fungsi pengawasan yang diberikan undangundang terhadap Bapepam-LK. Kegiatan pemeriksaan dilakukan terhadap semua pihak yang diduga telah, sedang, atau mencoba melakukan atau menyuruh, turut serta, membujuk, atau membantu melaku-kan pelanggaran terhadap undang-undang pasar modal dan peraturan pelaksananya. ${ }^{16}$ Dalam menjalankan pemeriksa-an, Bapepam-LK memiliki wewenang untuk: ${ }^{17}$

1. Meminta keterangan dan atau konfirmasi dari pihak yang diduga melakukan atau terlibat dalam pelanggaran terhadap undang-undang ini dan atau peraturan pelaksanaannya atau pihak lain apabila dianggap perlu;

2. Mewajibkan pihak yang diduga melakukan atau terlibat dalam pelanggaran terhadap undangundang ini dan atau peraturan pelaksanaannya untuk melakukan atau tidak melakukan kegiatan tertentu;

3. Memeriksa dan atau membuat salinan terhadap catatan, pembukuan, dan atau dokumen lain, baik milik Pihak yang diduga melakukan atau terlibat dalam pelanggaran terhadap undangundang ini dan atau peraturan pelaksananya maupun pihak lain apabila dianggap perlu; dan atau

\footnotetext{
${ }^{13}$ Nilasari.

14 Sujatmiko and Suryanti.

15 Pasal 1 angka 7 Undang-Undang Nomor 8 Tahun 1995 Tentang Pasar Modal

${ }^{16}$ Febry Wulandari and W Waluyo, 'Efektivitas Pemanfaatan Dana Bagi Hasil Cukai Hasil Tembakau Dalam Bidang Kesehatan Di Kota Surakarta Tahun 2018', Jurnal Bestuur, 7.1 (2019).

${ }^{17}$ Kiandi.
} 
4. Menetapkan syarat dan atau mengizinkan Pihak yang diduga melakukan atau terlibat dalam pelanggaran terhadap undang-undang ini dan atau peraturan pelaksanaannya untuk melakukan tindakan tertentu yang diperlukan dalam rangka penyelesaian kerugian yang timbul.

Jika Bapepam-LK berpendapat bahwa pelanggaran terhadap undang-undang pasar modal dan peraturan pelaksananya mengakibatkan kerugian di industri jasa pasar modal serta membahayakan kepentingan hak-hak investor, maka Bapepam-LK menetapkan dimulainya tindakan penyidikan. Penyidikan ini dilakukan oleh Pejabat Pegawai Negeri Sipil tertentu di lingkungan Bapepam-LK. Tindakan Bapepam-LK berupa pemeriksaan dan penyidikan merupakan proses kegiatan pengawasan yang bertujuan memberi perlindungan dan kepastian hukum bagi kalangan investor. Dalam hal memberikan perlindungan hukum bersifat represif, menurut UUPM memiliki kewenangan untuk memberikan sanksi administratif berupa peringatan tertulis, denda, pembatasan kegiatan usaha, pembekuan kegiatan usaha, pencabutan izin usaha, pembatalan persetujuan, dan pembatalan pendaftaran. Selain itu, UUPM juga memberikan sanksi pidana terhadap pelaku pelanggaran dan atau kejahatan di bidang jasa pasar modal. ${ }^{18}$

\section{Perlindungan Hukum Bagi Investor Menurut Undang-Undang Nomor 21 Tahun 2011 Tentang Otoritas Jasa Keuangan}

OJK memiliki tugas salah satunya adalah menegakkan perlindungan konsumen jasa keuangan di Indonesia. Perlindungan konsumen dalam pasar modal selanjutnya akan disebut sebagai perlindungan investor pasar modal karena konsumen dalam sektor pasar modal adalah pemodal atau investor. Maka dari itu, aspek perlindungan terhadap investor pasar modal menjadi kewenangan OJK. Perihal perlindungan konsumen tercantum dalam Pasal 28, Pasal 29, dan Pasal 30 UU OJK yang merupakan ketentuan-ketentuan yang mengatur secara eksplisit perihal perlindungan konsumen dan masyarakat atas industri jasa keuangan. ${ }^{19}$

Bentuk perlindungan hukum yang dilakukan OJK terhadap konsumen bersifat pencegahan atau preventif dan pemberian sanksi atau represif, mengingat bahwa tugas OJK adalah menjalankan fungsi pengaturan dan pengawasan sektor jasa keuangan. Pasal 28 UU OJK memberikan perlindungan hukum bersifat pencegahan kerugian konsumen dan masyarakat yang dilakukan oleh OJK adalah: ${ }^{20}$

1. Memberikan informasi dan edukasi kepada masyarakat atas karakteristik sektor jasa keuangan, layanan, dan produknya;

2. Meminta Lembaga Jasa Keuangan untuk menghentikan kegiatannya apabila kegiatan tersebut berpotensi merugikan masyarakat; dan

3. Tindakan lain yang dianggap perlu sesuai dengan ketentuan peraturan perundang-undangan di sektor jasa keuangan.

Khusus Pasal 29 UU OJK menyatakan, bahwa OJK melakukan pelayanan pengaduan Konsumen yang meliputi: ${ }^{21}$

1. Menyiapkan perangkat yang memadai untuk pelayanan pengaduan Konsumen yang dirugikan oleh pelaku di Lembaga Jasa Keuangan;

2. Membuat mekanisme pengaduan Konsumen yang dirugikan oleh pelaku di Lembaga Jasa Keuangan;

18 Indonesia SIPF, 'Annual Report Securities Investor Protection Fund Indonesia', Securities Investor Protection Fund, 12 (2019), 1-243 <http://indonesiasipf.co.id/laporan-tahunan>.

${ }^{19}$ I.G.A.K. Rachmi Handayani, Lego Karjoko, and Abdul Kadir Jaelani, 'Model Pelaksanaan Putusan Mahkamah Konstitusi Yang Eksekutabilitas Dalam Pengujian Peraturan Perundang-Undangan Di Indonesia', Bestuur, 7.1 (2019), 36-46 <https://jurnal.uns.ac.id/bestuur/article/view/42700>.

${ }^{20}$ Fadlia and .

${ }^{21}$ Muharam. 
3. Memfasilitasi penyelesaian pengaduan Konsumen yang dirugikan oleh pelaku di Lembaga Jasa Keuangan sesuai dengan peraturan perundang-undangan di sektor jasa keuangan.

Bentuk perlindungan hukum lainnya yang bersifat represif adalah jika terjadi sengketa antara konsumen dengan perusahaan industri jasa keuangan, maka OJK berwenang melakukan pembelaan hukum demi kepentingan konsumen dan masyarakat. Pembelaan hukum tersebut meliputi memerintahkan perusahaan jasa keuangan untuk menyelesaikan pengaduan yang dilakukan oleh konsumen yang merasa dirugikan melalui cara:

1. Memerintahkan atau melakukan tindakan tertentu kepada Lembaga Jasa Keuangan untuk menyelesaikan pengaduan konsumen yang dirugikan Lembaga Jasa Keuangan dimaksud;

2. Mengajukan gugatan untuk memperoleh kembali harta kekayaan milik pihak yang dirugikan dari pihak yang menyebabkan kerugian, baik yang berada di bawah penguasaan pihak yang menyebabkan kerugian dimaksud maupun di bawah penguasaan pihak lain dengan itikad tidak baik; dan/atau untuk memperoleh ganti kerugian dari pihak yang menyebabkan kerugian pada konsumen dan/atau Lembaga Jasa Keuangan sebagai akibat dari pelanggaran atas peraturan perundang-undangan di sektor jasa keuangan.

Landasan filosofis bahwa lembaga OJK memberikan perlindungan hukum adalah asas-asas yang mendasari OJK dalam melaksanakan tugas dan wewenangnya, yaitu:

1. Asas independensi, yakni independen dalam pengambilan keputusan dan pelaksanaan fungsi, tugas, dan wewenang OJK dengan tetap sesuai peraturan perundang-undangan yang berlaku;

2. Asas kepastian hukum, yakni asas dalam negara hukum yang mengutamakan landasan peraturan perundang-undangan dan keadilan dalam setiap kebijakan penyelenggaraan Otoritas Jasa Keuangan;

3. Asas kepentingan umum, yakni asas yang membela dan melindungi kepentingan konsumen dan masyarakat serta memajukan kesejahteraan umum;

4. Asas keterbukaan, yakni asas yang membuka diri terhadap hak masyarakat untuk memperoleh informasi yang benar, jujur, dan tidak diskriminatif tentang penyelenggaraan Otoritas Jasa Keuangan, dengan tetap memperhatikan perlindungan atas hak asasi pribadi dan golongan, serta rahasia negara, termasuk rahasia sebagaimana ditetapkan dalam peraturan perundang-undangan;

5. Asas profesionalitas, yakni asas yang mengutamakan keahlian dalam pelaksanaan tugas dan wewenang Otoritas Jasa Keuanga, dengan tetap berlandaskan pada kode etik dan ketentuan peraturan perundang-undangan;

6. Asas integritas, yakni asas yang berpegang teguh pada nilai-nilai moral dalam setiap tindakan dan keputusan yang diambil dalam penyelenggaraan Otoritas Jasa Keuangan; dan

7. Asas akuntabilitas, yakni asas yang menentukan bahwa setiap kegiatan dan hasil akhir dari setiap kegiatan penyelenggaraan Otoritas Jasa Keuangan harus dapat dipertanggungjawabkan kepada publik.

Perlindungan konsumen sektor jasa keuangan di bawah rezim OJK menaungi seluruh sektor jasa keuangan meliputi lembaga keuangan bank maupun lembaga keuangan non-bank. Penyatuan pengaturan perlindungan konsumen sektor jasa keuangan yang selama ini terpencar dimaksudkan untuk memperbaiki sistem serta menutup kekurangan-kekurangan substansial. Hal ini senada dengan pernyataan Ketua Dewan Komisioner OJK, Muliaman Darmansyah Hadad : ${ }^{22}$

"Aturan perlindungan konsu-men selama ini terpencar, bank punya sendiri, pasar modal ada.

Namun sekarang kita gabung-kan jadi satu dengan upaya memperbaiki substansinya.

22 C.D. Balenina, 'Partisipasi Masyarakat Dalam Pengelolaan Desa Sampah Mandiri Di Desa Kalisoro, Tawangmangu, Kabupaten $\quad$ Karanganyar', $\quad B e s t u u r, \quad 7.1 \quad$ (2019), 26-35 <https://doi.org/https://dx.doi.org/10.20961/bestuur.v7i1.28418>. 
Sehingga nantinya akan ada penekanan, misalnya kewajiban bagi bank dan lembaga keuangan lain yang menyedia-kan pelayanan informasi bagi calon nasabah."

\section{PENUTUP}

Tidak terpenuhinya hak investor sebagai konsumen jasa keuangan pasar modal berupa hak atas informasi yang benar, jelas tentang kondisi jasa keuangan remote trading system dan hak untuk mendapatkan pembinaan serta edukasi tentang sistem transaksi efek beserta back up system, menyebabkan terlanggarnya aspek perlindungan konsumen bagi investor di bursa. Perlindungan hukum bagi investor menurut Undang-Undang Nomor 8 Tahun 1995 Tentang Pasar Modal dan Undang Undang Nomor 21 Tahun 2011 Tentang Otoritas Jasa Keuangan bersifat preventif dan represif. Perlindungan hukum bersifat preventif ditunjukkan dari ketentuan-ketentuan yang mengaruskan pembinaan, edukasi serta pengawasan dari otoritas bursa dan pengawas, sedangkan perlindungan hukum bersifat represif adanya penerapan sanksi berupa sanksi administratif sebagai ultimum remedium bagi para pihak yang melanggar aturan hukum dalam regulasi pasar modal. Lembaga yang berwenang untuk melakukan ini adalah OJK. Jika terjadi sengketa antara konsumen (investor) dan otoritas SRO maka dapat diselesaikan melalui litigasi ataupun non-litigasi dengan memanfaatkan lembaga BPSK dan alternatif penyelesaian sengketa khusus pasar modal, yaitu BAPMI.

\section{References}

Balenina, C.D., 'Partisipasi Masyarakat Dalam Pengelolaan Desa Sampah Mandiri Di Desa Kalisoro, Tawangmangu, Kabupaten Karanganyar', Bestuur, 7.1 (2019), 26-35 <https://doi.org/https://dx.doi.org/10.20961/bestuur.v7i1.28418>

Fadlia, Dian Husna, and . Yunanto, 'Peran Otoritas Jasa Keuangan (Ojk) Dalam Perlindungan Hukum Bagi Investor Atas Dugaan Investasi Fiktif, Law Reform, 11.2 (2015), 207 $<$ https://doi.org/10.14710/lr.v11i2.15768>

Handayani, I.G.A.K. Rachmi, Lego Karjoko, and Abdul Kadir Jaelani, 'Model Pelaksanaan Putusan Mahkamah Konstitusi Yang Eksekutabilitas Dalam Pengujian Peraturan Perundang$\begin{array}{lllll}\text { Undangan Di Indonesia', Bestuur, } 7.1 \quad \text { (2019), } & \text { 36-46 }\end{array}$ $<$ https://jurnal.uns.ac.id/bestuur/article/view/42700>

Kiandi, Ferry, 'Perlindungan Hukum Dalam Transaksi Margin Trading Dan Short Sales Di Pasar Modal', FH Universitas Sumatera Utara, 2014, 1-18

Made, Oleh, and Dwi Juliana, 'Perlindungan Hukum Terhadap Investor Bila Terjadi Insider Trading Dalam Pasar Modal', Kertha Wicara, Vol.2, No. (2013), 1-5

Muharam, Noviasih, 'Perlindungan Hukum Bagi Investor Dalam Pembelian Kembali Sahamnya', Pranata Hukum, 13.1 (2018), 59-71 <https://doi.org/10.36448/pranatahukum.v13i1.177>

Nilasari, Rahmadiani Putri, 'Perlindungan Hukum Terhadap Investor Dalam Transaksi Jual Beli Efek Melalui Internet', Yuridika, $26.3 \quad$ (2011), 275-86 <https://doi.org/10.20473/ydk.v26i3.279>

Nuryanto, Ahmad Dwi, 'Problem Penyidikan Tindak Pidana Pencucian Uang Yang Berasal Dari $\begin{array}{lllll}\text { Predicate Crime } \quad \text { Perbankan', Bestuur, } & 7.1 & \text { (2019), } & 54\end{array}$ <https://doi.org/10.20961/bestuur.v7i1.43437>

Rahadiyan, Inda -, and Diah Ayu Ambarsari, 'Ketiadaan Batas Waktu Suspensi Dan Implikasinya Terhadap Perlindungan Investor Pasar Modal Indonesia', Jurnal Hukum Ius Quia Iustum, 25.2 (2018), 300-319 < https://doi.org/10.20885/iustum.vol25.iss2.art5>

SIPF, Indonesia, 'Annual Report Securities Investor Protection Fund Indonesia', Securities Investor Protection Fund, 12 (2019), 1-243 < http://indonesiasipf.co.id/laporan-tahunan> 
Sujatmiko, Bagus, and Nyulistiowati Suryanti, 'Perlindungan Hukum Bagi Investor Pada Perusahaan Terbuka Yang Pailit Ditinjau Dari Hukum Kepailitan', Jurnal Bina Mulia Hukum, 2.1 (2017), 15-25 <https://doi.org/10.23920/jbmh.v2n1.2>

Susanti, Liana E, 'Economic Law Creation Beautiful Global Indonesia', Bestuur, 7.1 (2019), 47-53 $<$ https://jurnal.uns.ac.id/bestuur/article/view/42701>

Wulandari, Febry, and W Waluyo, 'Efektivitas Pemanfaatan Dana Bagi Hasil Cukai Hasil Tembakau Dalam Bidang Kesehatan Di Kota Surakarta Tahun 2018', Jurnal Bestuur, 7.1 (2019) 